\title{
Taiwan Elections 2008: Ma Ying-jeou's Victory and the KMT's Return to Power
}

\section{Frank Muyard}

\section{(2) OpenEdition \\ 1 Journals}

Electronic version

URL: http://journals.openedition.org/chinaperspectives/3423

DOI: 10.4000/chinaperspectives.3423

ISSN: 1996-4617

\section{Publisher}

Centre d'étude français sur la Chine contemporaine

\section{Printed version}

Date of publication: 1 January 2008

Number of pages: 79-94

ISSN: 2070-3449

\section{Electronic reference}

Frank Muyard, «Taiwan Elections 2008: Ma Ying-jeou's Victory and the KMT's Return to Power », China Perspectives [Online], 2008/1 | 2008, Online since 01 January 2011, connection on 28 October 2019.

URL : http://journals.openedition.org/chinaperspectives/3423 ; DOI : 10.4000/chinaperspectives.3423 


\title{
Taiwan Elections 2008: Ma
}

\section{Ying-jeou's Victory and the} KMT's Return to Power

\author{
FRANK MUYARD
}

After eight years of DPP administration, the 2008 legislative and presidential polls in Taiwan saw the Kuomintang return to power with the election of Ma Ying-jeou as the new president and an increased majority in the Parliament. Apart from the circumstantial factors behind this double victory, a detailed analysis of the poll results and comparisons with the results of previous elections reveals the recent evolution of an electorate that remains structurally oriented towards the KMT.

\section{Introduction}

1 aiwan's legislative and presidential elections in January and March 2008 marked a turning point in the country's political development. With the accession of Ma Ying-jeou to the presidency of the Republic of China (the official name for Taiwan), the Chinese Nationalist Party or Kuomintang (KMT) has recaptured executive power after eight years of administration by the Democratic Progressive Party (DPP). Backed by its increased majority in Parliament, the KMT now has full power to implement its programme. Looking beyond results, these elections also mark a resounding success for Taiwanese democracy and its consolidation. Unlike 2004, when defeated KMT candidates challenged the results with street demonstrations and legal manoeuvres even though the organisation of the polling had been exemplary, this year's presidential election took place without incident, and the result was immediately accepted by the DPP. The KMT's victory brings a second switch of power in eight years, and confirms the bedding down of democratic institutions and practices on the island. In this article, we will look back at the legislative elections before analysing in detail the results of the presidential poll and the lessons to be drawn from it. Finally, we will examine the challenges that the new president confronts over the economy, relations with China, and national identity. ${ }^{(1)}$

\section{Legislative elections}

\section{Analysis of the results}

The elections for the new Taiwanese parliament, the Legislative Yuan (LY), were held on 12 January 2008. The poll presented some new developments compared with earlier elections. Only 113 seats were at stake, the number halved since the last election, and legislators faced a term of four years as against three previously. The voting system was also changed, the multi-member constituency system ${ }^{(2)}$ having been abandoned in favour of a "single-member district, two vote" system. Seventy-three deputies were directly elected in single-member constituencies, while a separate vote distributed 34 seats proportionally to political party lists, and six seats were reserved for Taiwan's aboriginal minority. At the same time, two referendums were held, one over the assets of the KMT (tabled by the DPP) and the other calling for action against corruption (tabled by the KMT).

The results gave a substantial victory to the KMT, which for the constituency vote brought under its name the whole of the Pan-Blue coalition (made up of the KMT, the People First Party - PFP - and the Chinese New Party - NP).

1. I would like to thank Mr. Hu Chih-chiang for its help in the research for this article.

2. On the legislative elections of 2004, cf. Frank Muyard, "KMT: A Trompe-l'oeil Victory: The December 2004 Taiwanese Legislative Elections," China Perspectives, n58, March-April 2005, p. 43-54. 
With 53.5 percent of the votes, the KMT and the PFP won 81 seats out of 113 , exceeding two thirds of the new parliament. With the additional support of four independent representatives, the Pan-Blue camp now controls up to three quarters of the LY, which gives it control over the country's legislation unequalled since the early 1990s. The DPP, on the other hand, suffered its worst defeat in 20 years, returning only 27 seats despite a relatively strong total of 38.17 percent of the votes.

The KMT's LY victory was expected. By itself or with its allies in the Pan-Blue camp, the KMT has actually won every legislative election in Taiwan since the country was democratised. Its long domination of Taiwan and its bedrock support within local politics, including a good voting network ensured by control of numerous local factions and associations, give it a definite electoral advantage. Opinion polls before the election had also predicted a KMT victory. Yet, the scale of the party's success came as a surprise, especially in terms of seats. Further analysis provides several explanations for this.

First, there were technical reasons. Because of the reduction in the number of representatives, and in order to guarantee that the Legislative Yuan included representatives from each county (xian) and municipality, the rules on equal political representation (prescribing one representative for every 300,000 electors approximately) were stretched a little to give one seat each to the less populated counties in East Taiwan (Hualien, Taitung) and the islands in the Strait of Formosa (Kinmen, Matsu, Penghu). The six seats reserved for aboriginal candidates also far exceed their demographic weight (the aborigines are 2 percent of the population). The traditional PanBlue inclinations of all these constituencies required the DPP to win decisively in the rest of the country, an unlikely prospect given the general structure of the electorate and the local predispositions in Taiwanese elections. The DPP itself only hoped to win at best 30 to 35 of the disputed constituencies by majority vote, an insufficient result to secure a majority in parliament. ${ }^{(3)}$ Finally, the system of first-past-the-post tends to exaggerate the results in terms of seats; in a sense, it offers additional rewards to the winners.

But while the new voting system considerably widened the gap in terms of seats, it cannot be blamed for the DPP's defeat. That was caused first and foremost by changes in the numbers of votes won by the competing camps. It would be deceptive to take into account only the DPP's and the KMT's results. In the constituency vote, the KMT achieved an increase of 20.7 percent compared with 2004, when it was competing with the PFP and the NP for the same electorate. The DPP on its side saw its share of the electorate grow by 2.5 percent, a result that has to be considered positive. In terms of the two camps, on the other hand, the Pan-Blue vote increased by 6.9 percent, while that of the Pan-Greens (that is, the DPP and the Taiwanese Solidarity Union, TSU) fell by 4.4 percent. Furthermore, while the gap between the camps favoured the Pan-Blues by only 3.3 percent in 2004, it jumped to 14.7 percent this time. The DPP made progress, but it did so essentially at the expense of the TSU, whose votes fell by 6.8 percent.

The gap between the two camps was reflected in the results of the voting on party lists. The slight fall in the KMT vote was made up by the NP's votes (3.95 percent), bringing the Pan-Blues an overall total of 55.2 percent. The TSU's 3.5 percent added to the DPP's 37 percent pushed the Pan-Green camp past the 40 percent mark. With less than 5 percent of the votes, however, neither the NP nor the TSU - or any other small party will be represented in the new Parliament.

The Pan-Blue camp not only won a clear victory in percentage terms, both in comparison with the Pan-Greens and with the independents (whose total fell by 2.54 percent), it also increased its tally by more than 760,000 additional votes. This advance marks a turning point in recent political history by reversing the continuing decline the Pan-Blues had been suffering since 1995. Their success in the legislative elections of 2004 had actually been somewhat deceptive: while the Pan-Blue camp kept its parliamentary majority, it lost 2.89 percent of its support and more than 580,000 individual votes - historically, its worst-ever performance. This time, by contrast, it regained voting levels equal to its success in the legislative elections of 1998, which preceded the rise to power of Chen Shui-bian and the DPP. Conversely, the PanGreen camp has lost more than 350,000 votes in four years, and 370,000 votes compared with the elections in 2001.

A detailed analysis of the turnout also gives us a more qualified picture of the abstention rate. In percentage terms, the turnout dropped once again to a record low of

3. Assuming the balance of power obtaining in 2004 , the Pan-Greens would have been able to win 31 seats out of 73 as well as 15 to 16 seats from their party lists by the proportional vote. The calculation was made by the author based on statistics provided in Liang Shih-wu et al., 21 shiji Taiwan toupiao jilu, Taipei, Taiwan shangwu yinshuguan, 2007. 


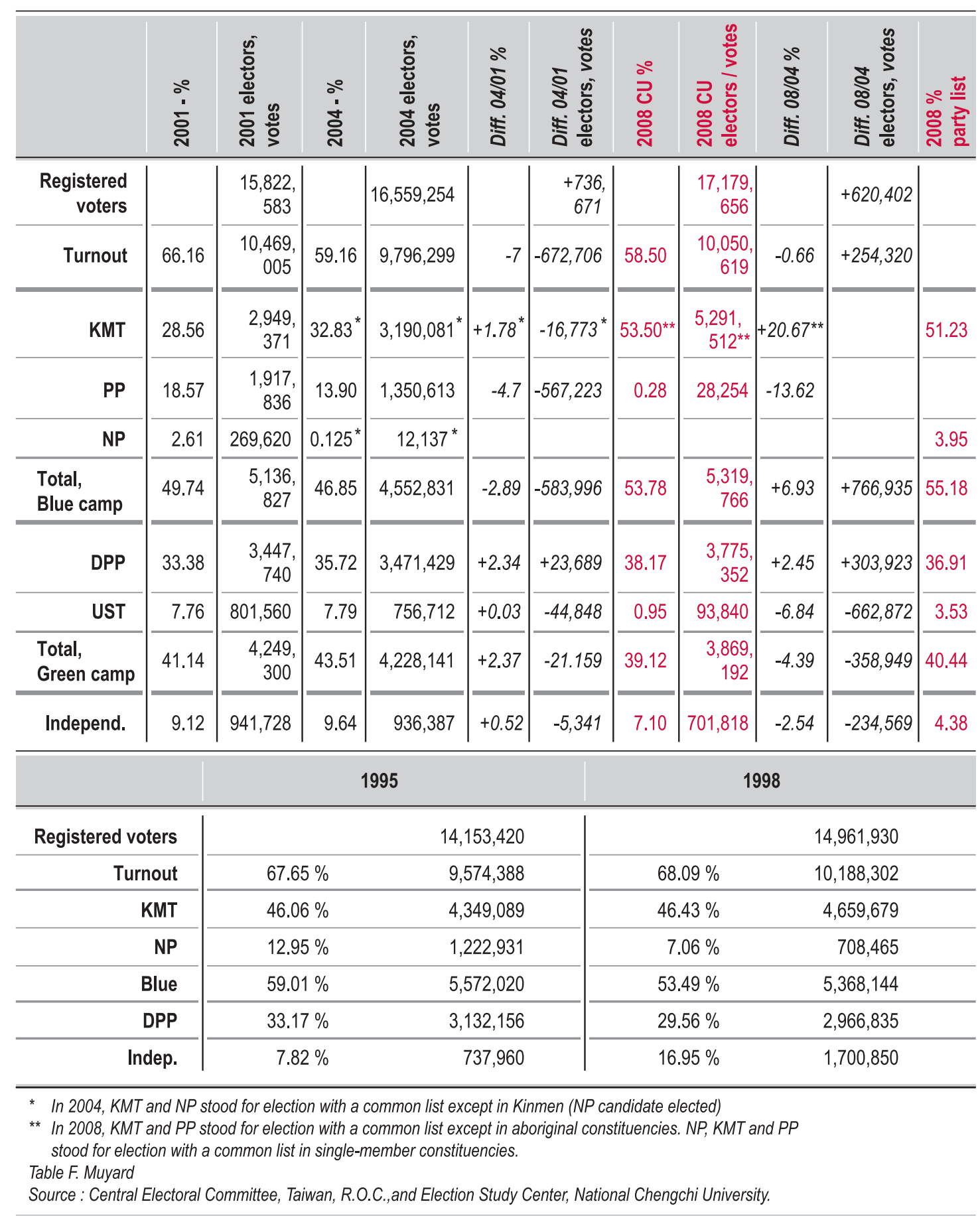

58.5 percent, as against 59.16 percent in 2004 . However, in absolute terms, the number of votes cast was quite high, up by more than 250,000 votes, indicating effective mobilisation, at least on the winning side. It actually equalled the voting tally of the 1998 LY elections. In fact, ever since 1995, around 9.5 to 10.5 million electors have been voting in the legislative elections. While the turnout has been falling steadily for ten years, from 68.1 percent down to 58.5 percent, this is because the continuing growth in the overall electorate automatically pushes down the percentage of voters. It is thus possible that mostly the same electors turn out to vote on each occasion - politically conscious and mainly committed people. At the same time, there is clearly an increase in the number of uncommitted, non-politicised voters, and of people disillusioned with politics who do not vote in 
the LY elections. That is particularly the case with many young people. ${ }^{(4)}$

An assessment of the results of the legislative elections since 1995 shows, in addition, that support for the Pan-Blue camp wavers between a minimum of 4.5 million and 46.8 percent of the votes (2004) and a maximum of 5.5 million votes (1995); results in 1998 and 2008 were fairly similar: 5.3 million and 53-55 percent of the votes. Thus, with the exception of 2004, the Pan-Blue camp has always won more than 5 million votes, which seems to be its average electoral base in parliamentary polling. On the Pan-Green side, the highest number of votes was achieved in 2001 and again in 2004 with 4.2 million; the best percentage was 43.5 percent in 2004; and the worst result was in 1998, with 2.9 million and 29.6 percent of the votes. ${ }^{(5)}$ The 3.8 million votes that it won in 2008 ( 40.4 percent) may be considered its new electoral base after eight years in power. It represents a real improvement compared with the 1990s, and reflects the overall increase in support for the Pan-Greens, from 30-33 percent during the 1990s to $40-43$ percent during the 2000s. The fluctuating performance of both camps in legislative elections can therefore be explained by the their ability to mobilise their own supporters while attracting a proportion of the undecided. In any case, assuming the PanBlues' regular potential to be higher than that of the PanGreens, barring exceptional circumstances, a victory for the Pan-Greens in parliamentary elections would remain difficult to achieve in the near future, especially in the context of the new electoral system.

\section{Causes and consequences of the KMT's win}

The first reasons behind the KMT's victory are its closer union with its allies and its greater mastery of the new voting system. After 15 years of division within the Pan-Blue camp, the KMT has at last succeeded in creating a solid electoral alliance with its partners, the PFP and the NP, thanks to a nominating process that gave the parties adequate representation and avoided any new fratricidal battles: 20 deputies - 25 percent - of the 80 candidates elected under the KMT banner are former PFP or NP members, to whom is added one PFP aboriginal candidate. This union was the condition for victory in a majority single-ballot electoral system, in which a divided camp usually turns out to be the poll's loser. The KMT was also able to field candidates with good local connections, and as always, it based its campaign on the local needs and concerns - particularly the economic concerns - of the population.
The Pan-Greens, by contrast, have flaunted their divisions. The disagreements between the DPP and the TSU prevented an effective electoral alliance and demobilised a proportion of their electorate. In addition there were rifts within the DPP, illustrated by a stormy nomination process that ultimately benefited the party's more radical wing. At least three safe Pan-Green seats in the south were thus lost because of a dissident TSU or DPP candidate. With a voting system requiring parties to raise the greatest number of votes, rather than merely gathering grass roots support as with the old system, the party's rejection of its own centrist candidates was clearly counter-productive in terms of both the party's image and the appeal of its candidates. In the end, the DPP lost all 11 of its marginal constituencies, as well as four constituencies it previously thought safe - this on top of the three lost through dissident activity. By comparison, the Pan-Blues held every one of the constituencies where they had majorities in 2004.

At bottom, the KMT's success is linked to two main causes: Firstly, the dissatisfaction of the Pan-Green and centrist electorate with the government and with President Chen Shui-bian, and secondly, the desire to see the KMT back in government, mainly because of its reputation for economic competence. Despite good economic indicators (5.7 percent growth and 3.9 percent unemployment in 2007), the stagnation and even reduction in the purchasing power of a proportion of the middle and poorer classes, as well as the continuing delocalisation of Taiwanese enterprises into China, have given people a sense of economic crisis. Such fears were intensified last year in the context of rising world energy and food prices and costlier housing.

Lastly, the DPP is paying for the tarnishing of its image as a clean party in the wake of a series of corruption scandals that have implicated associates of the President and the government since mid-2005. Corruption has always been a major concern among Taiwanese people in their electoral choices. In a campaign whose few national themes have focused - as in previous elections - on national identity (a DPP strength) and on the economy and governmental competence (KMT strengths), the Pan-Blues succeeded in reversing previous perceptions of their own corruption, and turned the anti-corruption theme against the DPP. In this

4. One explanation is the persistent habit of registering at the electoral office near the family home, and not the one near the individual's home. Thus, a large number of students and young workers originating from the centre and the south but living in the north are unwilling or unable to return to their parents' home for the legislative elections. By contrast, when it comes to the presidential elections, they do generally make the trip.

5. 1998 witnessed a very high percentage of votes going to independent candidates. 
The election finished with an outright victory for $\mathrm{Ma}$, with 58.45 percent of the vote

(C) AFP

context, the record abstentions also reflect the desire of PanGreen and centrist voters to teach the DPP a lesson.

Among its supporters, the DPP also finds itself reproached, on the one hand, with not having sufficiently advanced the pro-independence programme, and with having failed to recover the unwarranted assets of the KMT or to change the system of local pro-KMT factions; and on the other hand for having failed to undertake the progressive reforms it promised in the political, social, and environmental fields. ${ }^{(6)}$ Some of these failures are due to opposition by the PanBlue-controlled parliament, which since 2001 has practised political sabotage aimed at blocking DPP policy; ${ }^{(7)}$ even so, the government has ultimately been held responsible because of its own mistakes and its perceived lack of administrative and economic competence.

The combined effect of the new voting system and the January results has had noteworthy consequences for the parliament. Firstly, the control of three quarters of the seats by the KMT and its allies has given them complete legislative freedom. The system enabling parliamentary committees to check and approve bills before the chamber votes on them can only delay their eventual enactment. The Pan-Blue camp will also be able to unilaterally launch the process for revising the constitution (though subject to popular approval in a referendum). A new political landscape defined by twoparty politics - or even by single-party politics, given the DPP's great weakness in parliament - could, in turn, lead to a revival of KMT factions and conflicts of interest, complicating the future Pan-Blue government's business. The reduction in the number of constituencies also favours the rise of individual power among deputies, their collusion with local and national lobbies, and the creation of personalised political machines to ensure their re-election. Because of the ever-increasing cost of electoral campaigns in Taiwan, incumbent representatives will thus enjoy a strong advantage in 2012, while the parties' control over their own deputies is likely to decline. Yet, the large number of voters with no political affiliations raises other possibilities. The DPP might make a comeback by basing its message on the voters' needs; alternatively, a third party might emerge, profiting either from possible socioeconomic problems that transcend the present political polarisation, or from new divisions within the KMT.

As for the two referendums proposed to voters on 12 January, the KMT boycott prevented the required 50 percent participation in both cases. ${ }^{(8)}$ This failure proved once again that referendums cannot work in Taiwan unless both camps agree on the question in advance; and it portended a similar outcome for the more controversial referendum proposed during the presidential election, on whether Taiwan should join or return to the UN.

\section{Presidential elections}

\section{Analysis of the results}

The fourth presidential election by direct universal suffrage in Taiwanese history was held on 22 March this year. On the DPP ticket were Frank Hsieh Chang-ting, former Mayor of Kaohsiung (1998-2005) and Prime Minister (2005-2006), and his running-mate Su Tseng-chang, former Governor of the county of Taipei (1997-2004) and Prime Minister (2006-2007). Opposing them on the KMT ticket were Ma Ying-jeou, former Mayor of Taipei (1998-2006), and Vincent Siew Wan-chang, Prime Minister during the presidency of Lee Teng-hui (1997-2000).

The shock inflicted on the DPP by its failure in the elections to parliament allowed some to expect a pendulum effect to operate in the presidential elections to counterbalance the KMT's excessive power in the chamber. Yet, that would require the DPP to recover undecided voters along with its own moderate electors who had abandoned it in January. The DPP would also need to confront the voters' desire for an end to the standoff in power between the executive and the parliament that a KMT presidency would bring. In any case, only a very high turnout, above 80 percent, could have produced an outcome that favoured the Pan-Greens, faced as they were with a Pan-Blue camp whose structural and tactical advantage was doubled by offering one of the most popular and media-friendly candidates in Taiwan's democratic history. The challenge for Hsieh was to adequately distance himself from Chen Shuibian and his administration while at the same time projecting himself as the best guarantor of Taiwanese identity and socioeconomic recovery, and unifying a Pan-Green camp divided between factions, tactics, and opposing strategies.

6. Cindy Sui, "Taiwan's Defeated Party Rebuilds," Asia Times Online, 22 April 2008.

7. Cf. Shelley Rigger, "The Unfinished Business of Taiwan's Democratization", in Nancy Bernkopf Tucker, Dangerous Straits. The U.S.-Taiwan-China Crisis, New York, Columbia University Press, 2005, pp.16-43. 
In the end, the election finished with an outright victory for $\mathrm{Ma}$, with 58.45 percent of the vote ( 7.6 million) as against 41.55 percent (5.4 million) for his opponents. While the win for Ma and Siew was both expected and forecast, its extent did surprise most pundits, as well as the politicians of both the DPP and the KMT. Admittedly, opinion polls had indicated a gap quite close to the eventual 17 percent; but the repeated underestimate of Pan-Green votes by public opinion polls before previous elections, as well as the parties' generally more reliable private polling, had suggested a less easy victory. ${ }^{(9)}$ In any event, the Taiwanese made a clear choice in favour of Ma and the KMT, with their programme for closer economic interaction with China and for maintaining the political status quo in the Taiwan Strait. This confirmation of the January vote challenged the widespread notion that legislative elections and presidential elections obey different logic. In fact, the same causes produced the same effects: voters expressed both their rejection of President Chen Shuibian's DPP government and their wish to give KMT leaders the means to implement their policies.

Concurrently with the presidential vote, two important referendums for Taiwan's international relations were held. The first, tabled by the DPP, appealed for the country to join the UN under the name of Taiwan. The second, tabled by the KMT, proposed that Taiwan should return to the UN under the name of the Republic of China (ROC) or any other acceptable name. While the DPP called for yes votes in both referendums to ensure that at least one should succeed, the KMT decided to actively boycott the DPP proposal and mildly support its own without calling on supporters to vote. Contrary to the expectations of some and the fears of others, notably in Beijing and Washington, the referendums did not play a central role either in the campaign or in the final result of the presidential vote. With a mere $36 \%$ turnout for each of them, both were invalided.

The KMT and its Pan-Blue voters preferred to ignore the strategic value of the referendums for future negotiations with China as well as their value in the expression of identity, because of their potential to provoke, because the US had openly opposed holding them, and because they felt the referendums were politically manipulated towards partisan ends. Still more than 6 million electors took part in both referendums. As in the January referendums, this was more than had voted for the DPP in the election.

If we compare the 2008 results with those in earlier presidential elections, we can identify some of the reasons for Ma's victory. To do that, we must compare the strength of the Pan-Blue and Pan-Green camps rather than the individ- ual candidates: this is because of the divisions within the Pan-Blue camp since the start of the 1990s Compared with 2004, when Chen and Lu Hsiu-lien won by only a whisker over Lien and Soong, one may note that the votes for the Pan-Blue candidate rose by more than 1.2 million, while those for the Pan-Green candidate dropped by a million. In effect, a million votes were transferred from the Pan-Greens to the Pan-Blues. In terms of geographic share, Ma dominated almost the whole country, including the symbolically important municipalities of the south, Chiayi, Tainan, and Kaohsiung; only five counties in the centre and the south (Yunlin, Chiayi, Tainan, Kaohsiung, and Pingtung) showed a slight majority for Hsieh. In 2004, Chen won all the counties and cities of the south with very large majorities, as well as the key counties of Changhua, Nantou, Taichung, and Ilan; this enabled him to counterbalance the traditional Pan-Blue majorities in the north and north-west. ${ }^{(10)}$

The turnout, at 76.33 percent, was down by four points. That may be explained partly by the fact that the results were largely predictable compared with previous presidential elections, but partly also because the polarisation of politics had caused a growing proportion of the electorate to lose interest. Yet, reflecting the growth of the registered electorate $(+814,443)$, the number that actually voted was roughly equal to that in 2004 , down by only 30,000 votes. While the election attracted proportionately fewer voters, the number of electors remained steady at 13.2 million, indicating very strong mobilisation of Pan-Blue and Ma supporters, as well as rank-and-file Pan-Greens.

Looking back to 2000, the picture is slightly different. Chen and Lu had won their first mandate thanks to the Pan-Blue

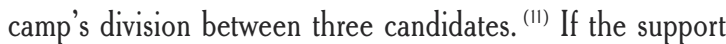
behind the Pan-Blue candidates in 2000 is added together, the result is close to the recent total: 7.6 million and 60.2 percent of the vote for the Pan-Blues, as against nearly five

8. Results of referendum $n^{\circ} 3$ (on the return of KMT assets alleged to be illegitimate) Turnout $26.34 \%, 4,550,881$ voters. Yes: $91.46 \%, 3,891,170$ votes. No: $8.54 \%, 363,494$ votes. Results of referendum $\mathrm{n}^{\circ} 4$ (for a public enquiry into corruption in government): Turnout $26.08 \%$, 4,505,927 votes. Yes: $58.17 \%$, 2,304,136. №: 41,83\%, 1,656,890.

9. Cf. Alan Romberg, "Taiwan Elections. Foundation for the Future," China Leadership Monitor, $n^{\circ}$ 24, spring 2008, p. 23, note 49; David Brown, "Taiwan Voters Set a New Course," Comparative Connections, April 2008, p. 3.

10. On the presidential election of 2004, cf. Frank Muyard, "Taiwan. The Birth of a Nation?", China Perspectives, n53, May-June 2004, p. 33-48.

11. Lien Chan and Vincent Siew Wan-chang (for the KMT), Soong Chu-yu and Chang Chaohsiung, and Lee Ao and Feng Yu-hsiang. There was also the independent candidacy of Hsu Hsin-liang and Chu Hui-liang with a strong Hakka colouring. Cf. Joseph Wu Jausieh, "After the Watershed, the Uncertainties: Assessing the Results of Taiwan's Presidential Election," China Perspectives, n²9, May - June 2000, p. 25-35. 
2. Results of the Presidential Elections in Taiwan (1996-2008)

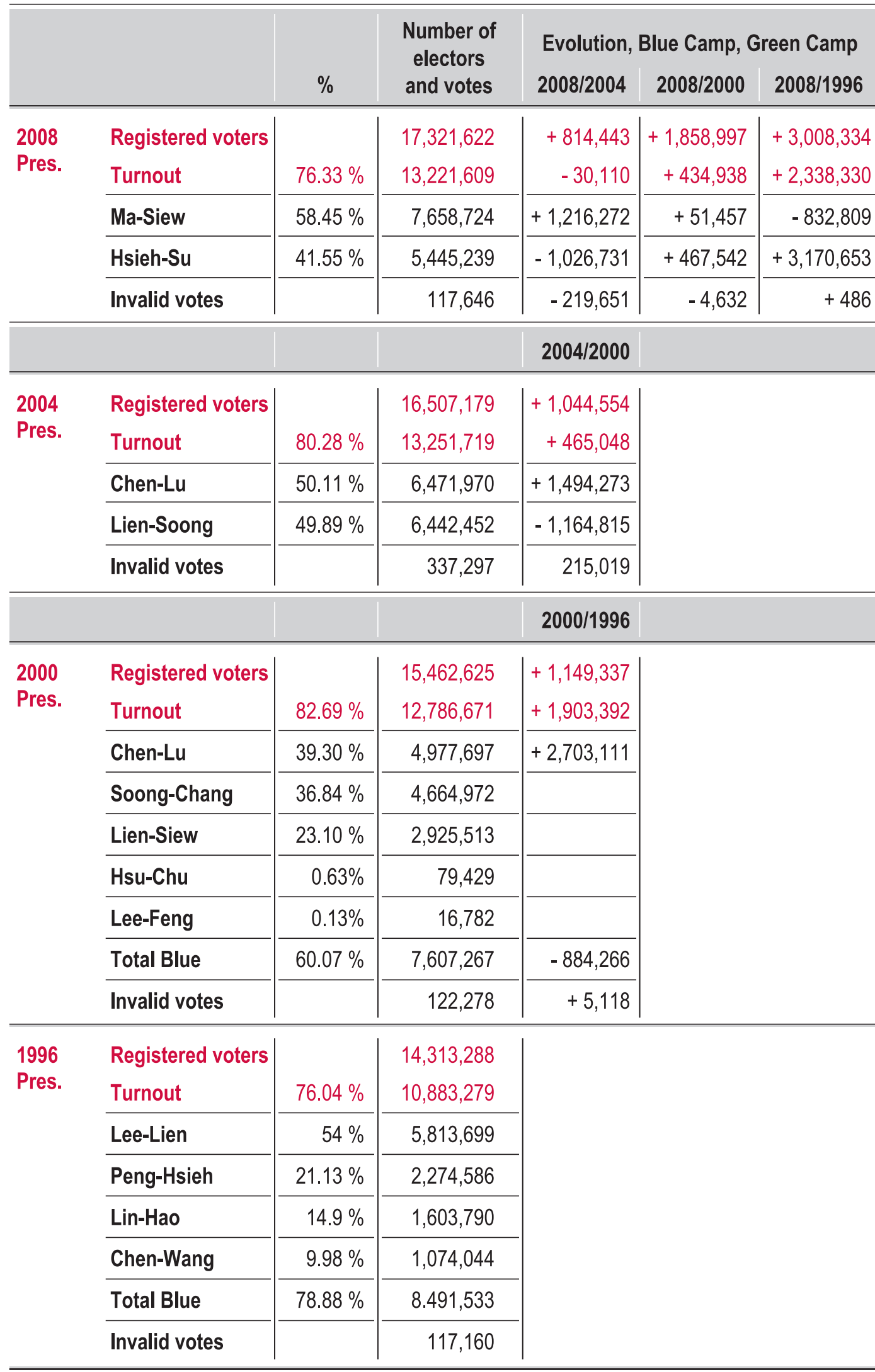


million and 39.3 percent of the vote for Chen and Lu. The similarity is repeated in the municipal and county results since 2000 , from which one can see that only the county of Tainan gave a majority to the DPP candidates in 2000.

All the other counties and municipalities in the south and centre were Pan-Blue, which helps us better understand the extent of Ma's success in the south. Here again, Ma is mainly picking up the Pan-Blue electorate of 2000. While the drop in Pan-Green numbers is very obvious compared with 2004, their result this year was still better than in 2000, winning five counties instead of one and an increased vote everywhere save Taipei.

Just as the parliamentary poll this year saw the KMT recover its support of 1998, the presidential election in March seems to present a return to the situation of 2000 in terms of the balance of power between Pan-Blues and PanGreens, with a slight improvement of 2.25 percent for the Pan-Greens. Moving on to the turnout, it was 82.69 percent in 2000, 6 percentiles higher than this year. But taking into account the increased number of registered voters $(+1,858,997)$, many more people actually voted this year $(+434,938)$. Now, in terms of votes, we can see that among these 434,000 new voters Ma picked up only 50,000 more than the divided Pan-Blues in 2000, whereas Hsieh won 467,000 , a higher total than the increase in voters. If we examine the 1996 election, we observe similar tendencies. With three million extra registered voters and 2.3 million extra votes in 2008, the Pan-Blues have lost 830,000 votes while the Pan-Greens have gained more than 3.1 million. These figures clearly illustrate the historic rise of the PanGreens, of Taiwanese nationalism, and indeed of Taiwanese pro-independence support since the first presidential election by universal suffrage in Taiwan.

But this analysis also confirms what we learned from the legislative elections: that the grassroots potential of the PanBlues has always been greater than that of the Pan-Greens. Over the past three presidential elections since 2000, the lowest vote for the Pan-Blues was 6.44 million in 2004, while the best was 7.65 million in 2000 and 2008. Turning to the Pan-Greens, however, their 6.47 million votes in 2004 was their peak performance, while the 5.45 million scored in 2008 probably represents their new electoral base. This illustrates, on the one hand, the exceptional nature of Chen's win in 2004, and on the other, the decoupling of Taiwanese national identity, still growing, from electoral preferences.

Before analysing the reasons behind Ma's victory, one must then explain the DPP's achievement in 2004. In that election, Chen Shui-bian profited from several factors favouring his re-election. Firstly, being the outgoing incumbent enabled him to attract the votes of independent or moderate local leaders by offering government support for their local development plans. In practice, the 11 percent boost in Chen's vote was also at least half due to the support he received from the TSU and Lee Teng-hui, who controlled part of the old KMT's pro-Taiwan local networks, particularly in the centre and the south - which by 2008 were tending to veer towards Ma. But Chen was also able to attract personal support by virtue of his charisma and his capacity for unifying the Pan-Green camp. People also wanted to give a new mandate to the DPP, another chance to show what it could do. Lastly, Chen and Lu were the spokespersons for Taiwanese identity and for the democratic and progressive movement of the previous 20 years, as opposed to Lien and Soong, who spoke for Chinese identity and were symbols of the KMT old guard. In fact, given the very slight margin of Chen's victory, if Ma had been the Pan-Blues' candidate at that time, there is little doubt that he would already have been elected in 2004.

A key role is thus played by the electors of the middle. Contrary to the conclusions reached by many DPP strategists since 2004, the variation in the votes achieved by DPP candidates in the last three elections (2000: 39.3 percent, 2004: 50.1 percent, 2008: 41.5 percent) proves the existence and importance of these floating voters, amounting to at least a 15-20 percent share of the electorate. While the Taiwanese electorate gives a structural majority to the Pan-Blues, the latter can in fact only obtain an absolute majority by bringing in centrist voters, as Lien's defeat in 2004 showed. Now, many of these unpoliticised electors are also in the geographical centre of the island - that is, in the counties of Taichung, Changhua, Nantou, and Yunlin - and they tend to offer their support to the incumbent candidate or to a probable winner. Another floating sub-group is that of new electors, mainly young people, who on the whole are less politicised and committed than their predecessors. Their votes are dictated more by present conditions, and they are sensitive to what is new, and to promises that their future will be improved.

\section{Causes of Ma's victory, and lessons to be drawn}

Yet, the structural predominance of the KMT in the Taiwanese electorate does not by itself explain Ma's victory or its extent. The Pan-Blue camp had also to fulfil a number of conditions to insure that it would not repeat its 2004 failure: fist, creating internal unit; second, choosing a charismatic can- 
3. Presidential Elections in Taiwan. Results by Counties and Municipalities (2000-2008)

\begin{tabular}{|c|c|c|c|c|c|c|}
\hline Results & $\begin{array}{c}2008 \text { Blue } \\
*\end{array}$ & $\underset{*}{2008 \text { Green }}$ & $\begin{array}{c}2004 \text { Blue } \\
* *\end{array}$ & 2004 Green & $\begin{array}{c}2000 \text { Blue } \\
* * *\end{array}$ & $\underset{* * *}{2000 \text { Green }}$ \\
\hline National & $58.45 \%$ & $41.55 \%$ & $49.89 \%$ & $50.11 \%$ & $60.24 \%$ & $39.30 \%$ \\
\hline Taipei & $63.03 \%$ & $36.97 \%$ & $56.53 \%$ & $43.47 \%$ & $61.81 \%$ & $37.64 \%$ \\
\hline Kaohsiung & $51.59 \%$ & $48.41 \%$ & $44.35 \%$ & $55.65 \%$ & $53.85 \%$ & $45.79 \%$ \\
\hline Taipei Co. & $61.05 \%$ & $38.95 \%$ & $53.06 \%$ & $46.94 \%$ & $62.75 \%$ & $36.73 \%$ \\
\hline Keelung & $67.73 \%$ & $32.27 \%$ & $59.44 \%$ & $40.56 \%$ & $68.66 \%$ & $30.84 \%$ \\
\hline Taoyuan & $64.64 \%$ & $35.36 \%$ & $55.32 \%$ & $44.68 \%$ & $66.10 \%$ & $31.12 \%$ \\
\hline Hsinchu & $64.70 \%$ & $35.30 \%$ & $55.12 \%$ & $44.88 \%$ & $65.37 \%$ & $33.79 \%$ \\
\hline Hsinchu Co. & $74.02 \%$ & $25.98 \%$ & $64.06 \%$ & $35.94 \%$ & $72.39 \%$ & $24.75 \%$ \\
\hline Miaoli & $70.99 \%$ & $29.01 \%$ & $60.75 \%$ & $39.25 \%$ & $71.96 \%$ & $26.81 \%$ \\
\hline Taichung & $61.74 \%$ & $38.26 \%$ & $52.66 \%$ & $47.34 \%$ & $62.68 \%$ & $36.86 \%$ \\
\hline Taichung Co. & $58.84 \%$ & $41.16 \%$ & $48.21 \%$ & $51.79 \%$ & $62.98 \%$ & $36.51 \%$ \\
\hline Changhua & $57.59 \%$ & $42.41 \%$ & $47.74 \%$ & $52.26 \%$ & $59.56 \%$ & $40.05 \%$ \\
\hline Nantou & $62.03 \%$ & $37.97 \%$ & $51.25 \%$ & $48.75 \%$ & $65.22 \%$ & $34.49 \%$ \\
\hline Yunlin & $48.47 \%$ & $51.53 \%$ & $39.68 \%$ & $60.32 \%$ & $52.72 \%$ & $46.99 \%$ \\
\hline Chiayi & $52.39 \%$ & $47.61 \%$ & $43.94 \%$ & $56.06 \%$ & $52.64 \%$ & $47.01 \%$ \\
\hline Chiayi Co. & $45.56 \%$ & $54.44 \%$ & $37.21 \%$ & $62.79 \%$ & $50.22 \%$ & $49.49 \%$ \\
\hline Tainan & $50.71 \%$ & $49.29 \%$ & $42.23 \%$ & $57.77 \%$ & $53.60 \%$ & $46.06 \%$ \\
\hline Tainan Co. & $43.85 \%$ & $56.15 \%$ & $35.21 \%$ & $64.79 \%$ & $45.98 \%$ & $53.78 \%$ \\
\hline Kaohsiung Co. & $48.59 \%$ & $51.41 \%$ & $41.60 \%$ & $58.40 \%$ & $52.52 \%$ & $47.14 \%$ \\
\hline Pingtung & $49.75 \%$ & $50.25 \%$ & $41.89 \%$ & $58.11 \%$ & $53.34 \%$ & $46.28 \%$ \\
\hline Ilan & $51.42 \%$ & $48.58 \%$ & $42.29 \%$ & $57.71 \%$ & $52.69 \%$ & $47.03 \%$ \\
\hline Hualien & $77.48 \%$ & $22.52 \%$ & $70.20 \%$ & $29.80 \%$ & $78.19 \%$ & $21.42 \%$ \\
\hline Taitung & $73.32 \%$ & $26.68 \%$ & $65.52 \%$ & $34.48 \%$ & $76.55 \%$ & $23.20 \%$ \\
\hline Penghu & $57.93 \%$ & $42.07 \%$ & $50.53 \%$ & $49.47 \%$ & $62.94 \%$ & $36.79 \%$ \\
\hline Kinmen & $95.13 \%$ & $4.87 \%$ & $93.95 \%$ & $6.05 \%$ & $96.46 \%$ & $3.11 \%$ \\
\hline Lienchiang & $95.16 \%$ & $4.84 \%$ & $94.24 \%$ & $5.76 \%$ & $97.96 \%$ & $1.80 \%$ \\
\hline
\end{tabular}

didate who could embody the electorate's desire for change and progress; and lastly, adopting an electoral programme and a message that took into account voters' wishes and the sociopolitical development of recent decades in terms of democratisation and Taiwanisation, and at the same time that might take advantage of disappointment with the DPP.
As in January, the main reasons for the KMT's win in March were thus voters' rejection of Chen and the DPP government, and the desire for a change of team after two terms under the Pan-Greens. To that was added, as in January, the wish for a unified cabinet and parliament after eight years of divided rule and political stalemate. The elec- 
torate was expressing its weariness with the constant tensions that marked the Chen Shui-bian era, both at home with the increase in partisan radicalisation, and abroad with rising tensions with China and disagreements with the US. A need for calm and stability, the electors' wish not to have political questions constantly distracting them from their own affairs, the hope of taking greater advantage of China's growth while maintaining the political status quo: these elements all played a definite role in bringing the KMT back to power.

But Ma's victory was also his own: that of a charismatic figure, a democrat, with a reputation for personal integrity. The sheer extent of his success gives him a special mandate that exceeds support for the KMT or its policies. And it was Hsieh's defeat. While the DPP's candidate had little chance given the general unpopularity of the Pan-Greens, Hsieh failed to attract more voter support for his reputation or his personality. His personal image - a competent administrator but cunning politician with a sometimes unsavoury entourage - could not match Ma's charisma and media skills. And, unlike Chen in 2004, Hsieh was unable to unify the Party and the Pan-Greens around his leadership. ${ }^{(12)}$ Admittedly, his campaign was effective, at the media level especially, and he put Ma in serious difficulty over his programme for economic rapprochement with China, forcing him to moderate it or spell it out, and over his personal integrity and leadership capacity. ${ }^{(13)}$ Even so, Hsieh did not campaign enough in person, travelling very little, and did not achieve the personal contact that is fundamental to Taiwanese politics, whereas $\mathrm{Ma}$ had toured the country since autumn, with "long stays" in the counties of the south and centre. So while Hsieh's campaign did rally the grassroots of the Pan-Green camp, it did not convince centrist voters or stimulate a higher turnout.

On political programmes, some rapprochements were noticed in the course of the campaign. ${ }^{(14)}$ However the two candidates did express differing views, mainly in a series of televised debates and numerous adverts on the following points: ${ }^{(15)}$ First, how quickly and how much should economic relations with China be strengthened in light of potential risks, strategic exposure, and economic dependence? Second, which economic and social policies should be developed to maintain Taiwanese prosperity in the areas of tax, sustainable development, and professional training? Third, what priority should be given to asserting Taiwan's national identity? Lastly, the candidates debated their own personal qualities. Now, while the repositioning of Hsieh's economic programme on relations with China did not con- vince either the radical Pan-Greens, who are opposed, or the centrists who prefer the KMT's original version, Ma's strategy of following the voters' lead on Taiwanese identity and democratic values did strike the right note.

Indeed, one of the most important aspects of this vote is that Ma Ying-jeou's victory is based on some fundamental assurances he has given in relation to Taiwan. From the start he declared loud and clear his Taiwanese identity ("I am Taiwanese"), and asserted Taiwan's sovereignty and its independence as the ROC. ${ }^{(16)} \mathrm{He}$ also committed himself to defending that sovereignty, and pledged that Taiwan's future could be decided only by Taiwan's 23 million citizens. Then Ma reaffirmed his attachment to the status quo with China, promising not to pursue unification in the short or medium term (that is, 30 to 50 years) and not to embark on any negotiations on the subject during his term of office. Lastly, he took a firm stand on democracy as the central value of Taiwanese society, setting China's democratisation as the precondition for any future unification. In fact, this position looks back to the conditions of Lee Teng-hui's Reunification Programme of 1991, but imposes far more precise barriers to unification than the positions taken on the question by Lien or Soong.

Ma also campaigned on the return to "real Taiwanese values," betrayed, he said, by the DPP. Backed by TV adverts stressing the links between the KMT and Taiwan - some of them in the Taiwanese language - and supported with a new Taiwanisation of the KMT's discourse, Ma and the KMT managed to sever the assumed connection between the DPP and the defence of Taiwanese interests and identity. Lastly, Ma was better able to express the openness to the outside world of the new Taiwanese society created by democracy with his campaign founded on the fresh opportunities of the future. By contrast, the DPP, unlike in the 1990s when it was swept along by the waves of democratisation and Taiwanisation and by the relative youthfulness of its leaders, has been appearing too involved with the past, with Taiwanese heritage, and nostalgia for a passing identity of

12. Cf. Cindy Sui, "Taiwan's Defeated Party Rebuilds," op. cit.

13. On the two candidates' campaigns, cf. the detailed assessment of Alan Romberg, "Taiwan Elections. Foundation for the Future," op. cit.

14. On the candidates' programmes, cf. "Presidential Election 2008. Profiles of Presidential Candidates," Taipei Times, 21 March 2008, as well as the campaign websites www.ma19.net and http://vivataiwan.tv.

15. Cf. the transcription of the main TV debate on 9 March, "Hsieh and Ma Face the Nation," and "Presidential Hopefuls Spar on Critical Issues," Taipei Times, 10 March 2008. For Ma's TV adverts, cf. http://www.ma19.net/video/ads; for those of Hsieh, http://vivataiwan.tv/index.php?sid=573\&page $=1$.

16. Mo Yan-chih and Shih Hsiu-chuan, "Defend Taiwan's Sovereignty, Says Ma," Taipei Times, 15 March 2008. 
former times. ${ }^{(17)}$ Paradoxically, the DPP of today missed the crystallisation of the new Taiwanese identity that it had done so much to create. Now that everyone is a democrat and everyone Taiwanese, even the KMT, it is no longer so necessary to fight for democracy and Taiwanese identity. It is time to look ahead, to seek what is new: this includes China, with its risks and opportunities, and the rest of the world.

\section{The view ahead: Three challenges for Ma}

As the new Taiwanese President, Ma Ying-jeou has great expectations to fulfil, notably insuring more peaceful crossStrait relations and greater prosperity at home. Yet, in both cases, many of the answers depend not on him but on the world economy and the attitude of Beijing. At the national level, Ma must quickly keep his promises and respect his commitments to Taiwan's voters. Having centred his electoral campaign on reviving the economy, he will have only a short honeymoon period in which to prove his competence. Also, he must improve relations with Washington, Taipei's indispensable backer. The US is already well disposed towards Ma because of his support for the status quo; but Washington will also have to show that it can help Taiwan at the international level, and will have complex choices to make in balancing its relations with Taiwan on the one hand, and China on the other, particularly in the areas of defence procurement and contacts and the free trade agreement that Taipei is seeking. Lastly, in his relationship with Beijing, $\mathrm{Ma}$ will have to exercise extreme caution so as not to appear to betray Taiwan's interests and sovereignty while winning from the Communist leadership what it denied to Chen Shuibian. Thus he will have three main challenges to confront, each linked to the others: the economy, relations with China, and national identity.

\section{The economy}

Ma has projected himself as the saviour of a failing economy that needs treatment. His programme promises 6 percent growth in 2008, unemployment below 3 percent by 2012, and a per capita GDP of US $\$ 30,000$ by 2016. To achieve these goals, he is counting on the swift opening up of direct air links with China and a mass influx of tourists from the mainland, the launch of 12 big infrastructure projects costing a total of US\$130 billion (25 percent of national GDP), and the transformation of Taiwan into a regional base for foreign multinationals investing in China.
Four years of negative publicity by the pro-Pan-Blue media (that is, two thirds of all Taiwanese media) have finally convinced a fair number of Taiwanese people that their economy is in crisis. The fact is, as we shall show, that the economic balance sheet from the Chen years is good, and the continuous success of the high technology sectors has boosted Taiwanese exports to a succession of new records. ${ }^{(18)}$ Even so, Taiwan faces two problems. The first is the economic restructuring brought about by globalisation and the relocation of businesses, to which all present-day developed economies are subject and face similar difficulties. Like the South Koreans, however, ${ }^{(19)}$ the Taiwanese population tends to forget the new barriers to growth presented by the country's high level of development, and compares its growth figures to those of China or other developing countries such as Vietnam or India, or even with the economies of entrepôt cities and financial centres such as Hong Kong and Singapore; this view generates mistaken assumptions about Taiwan's real performance. The second problem, linked to the first, is the crucial issue of purchasing power and the redistribution of national wealth towards the middle and poorer classes, a problem that affects the whole of the region. ${ }^{(20)}$ An important argument in the KMT's campaign was to dwell on Taiwan's growing social inequality. This problem is indeed central to the impression of relative decline shared by a section of the population, but it will not be easy to solve. In any case, a comparison with other countries at the same economic level shows Taiwan's position to be quite good.

GDP growth during Chen's time, from 2000 to 2007, averaged 4.1 percent per year, ${ }^{(21)}$ compared with 6.5 percent in the 1990s and 8.2 percent in the 1980s. This is a classic feature of industrial and technological development: growth rates decline as national wealth increases. Taking Chen's two terms separately, we see that from 2000 to 2003 , average annual growth was 2.9 percent, including a recession in

17. Liang Wen-chieh, "The DPP Must Rethink its Strategy," Taipei Times, 7 April 2008.

18. Cf. François Blanc, "Bilan économique des années Chen Shui-bian », La Lettre de Taiwan, $\mathrm{n}^{\circ}$ 144, April 2008, p. 2-7.

19. In respect of the economic situation as well as recent political developments, similarities between Taiwan and South Korea are in fact quite numerous. Cf. for example Philippe Pons, "Corée du Sud, nouvelle donne politique," Le Monde, 29 February 2008.

20. Cf. International Monetary Fund, Regional Economic Outlook. Asia and Pacific, Chap. IV, "Rising Inequality and Polarization in Asia," September 2006.

21. The assessment of the Taiwanese economy in the following paragraphs is based on government statistics supplied by the Directorate General of Budget, Accounting and Statistics (DGBAS) (cf. MacroEconomics Database, http://61.60.106.82/pxweb/ Dialog/statfile1L.asp?lang=1\&strList=L); based also on Taiwan's Economic Situation and Outlook, Council for Economic Planning and Development, March 2008, and Taiwan Statistical Data Book 2007, CEPD, Executive Yuan, R.O.C., Taiwan, June 2007. 
2001 (-2.2 percent) largely attributable to the bursting of the world dot-com bubble and the subsequent American recession. Between 2004 and 2007, growth averaged 5.2 percent, finishing in 2007 with 5.7 percent, which is close to the rate of 5.8 percent achieved during Lee Teng-hui's final term in 1996-99. Looking at regional comparisons, it appears that over the decade 1997-2007, Singapore grew at an average of 5.6 percent and South Korea at 4.4 percent, as against Taiwan's 4.5 percent. ${ }^{(22)}$ Yet, in terms of per capita GDP, Taiwan grew slightly faster than its rivals (3.96 percent annually, as against 3.55 percent for Singapore and 3.83 percent for South Korea) because of their higher population growth. Over the period 2004-2007, South Korea grew by 4.75 percent annually, again more slowly than Taiwan. ${ }^{(23)}$ Although the KMT claimed during its campaign that South Korea had overtaken Taiwan - with an annual per capita GDP of US\$20,045 as against Taiwan's US\$16,690 in 2007 - this catching up was mainly due to higher inflation and the rise of the South Korean Won against the US dollar, contrasting with Taipei's low inflation and restrictive monetary policy. ${ }^{(24)}$ If we look at per capita GDP in terms of Purchasing Power Parity (PPP), Taiwan's lead over South Korea is still substantial: US\$30,100 as against US\$24,800 in 2007. ${ }^{(25)}$ From this angle, then, the economy bequeathed by the DPP to the new Ma government looks extremely healthy.

Turning to employment levels, the unemployment rate in Taiwan was 3.9 percent in 2006 and 2007. While that figure is much to be envied in many developed countries, it is considered too high by a population that experienced full employment until the 2001 recession. Unemployment subsequently shot up from 2.69 percent in 2000 to 4.57 percent in 2001 , and on to a record 5.17 percent in 2002, falling gradually since then. Yet, we should note at the same time a rise in the percentage of the active population (sometimes a forced choice) from 57.2 percent of those of working age in 2001 to 58.3 percent in 2007. That represents a million extra people in the labour market in seven years, and as many jobs created (they were 30,000 less unemployed people in 2007 compared with 2001). A glance back at the 1990s also shows that the rise in unemployment predates Chen's coming to power. From 1992 to 1995, when unemployment averaged 1.57 percent (1.87 percent between 1979 and 1995), the rate jumped to 2.6 percent in 1996 and remained at an average of 2.73 percent between 1996 and 1999. It was precisely at this time, economists believe, that the shift of Taiwanese manufacturing to Southeast Asia and China at the end of the 1980s began to have a strong negative impact on employment and purchasing power in Taiwan. ${ }^{(26)}$
In terms of social inequality, a marked rise in the income gap between rich and poor was apparent at the start of the 2000s, reflecting the recession and the accelerating rate of industrial migration into China, notably by Taiwan's IT sector. ${ }^{(27)}$ The Gini coefficient reached a peak of 0.350 in 2001, falling to 0.339 in 2006. But the truth is that the coefficient had already been rising steadily since 1980 , from 0.277 to 0.326 by 2000 , and actually rose more precipitously between 1992 and 2000 $(+0.024)$ than between 2000 and $2006(+0.013)$. The income gap between the richest 20 percent of households and the poorest 20 percent also rose steadily from 4.17 in 1980 to 5.5 in 1999. After that it climbed to 6.39 in 2001 before falling back to 6.01 in 2006. So, while the gap was at its worst during the DPP's period in office, the increase was part of a long-term process that reached its peak during the 2001 recession and has since improved, although remaining higher than 1990s levels. These figures are relatively good in the international context, reflecting a rather egalitarian society in comparison with rising social inequality elsewhere in Asia, especially South Korea. ${ }^{(28)}$

The main problem remains the stagnation of incomes and especially of wages since 2000 . Although the total value of goods and services rose 47.8 percent from 2001 to 2006, the average wage increased by only 7.1 percent. ${ }^{(29)}$ Between 2000 and 2007, total wage growth was limited to 7.6 percent, only 1.7 percent more than inflation during the same period, while productivity jumped 48.7 percent. ${ }^{(30)}$ The

22. Hwan C. Lin, "Taiwan's Economy is not Bad Off", Taipei Times, 3 March 2008.

23. Cf. IMF, World Economic Outlook Database, March 2008.

24. Ibid.

25. Cf. Ibid. By comparison, annual GDP per capita in PPP (expressed in US dollars in 2007) of the US was $\$ 45,800$, UK $\$ 35,300$, Germany $\$ 34,200$, Japan $\$ 33,600$, France $\$ 33,200$, and Spain $\$ 30,100$. Figures for Hong Kong and Singapore respectively were $\$ 42,000$ and $\$ 49,700$. China's figure is $\$ 5,300$. Expressing GDP per capita in PPP helps to correct currency fluctuations and to compare the real cost of living in different countries.

26. CF T. J. Cheng, "China-Taiwan Economic Linkage: Between Insulation and Superconductivity," in N. Tucker, Dangerous Straits. The U.S.-Taiwan-China Crisis, op. cit., pp. 93-130.

27. Cf. ibid., and Craig Meer, Jonathan Adams, "Specter of Inequality Haunts Taiwan," Far Eastern Economic Review, vol. 169, n 10, December 2006, pp. 38-42.

28. Cf. IMF, Regional Economic Outlook. Asia andPacific, op. cit. Thus, while Taiwan's Gini coefficient is higher than that of Germany $(0.283)$, France $(0.327)$, and South Korea (0.331), it is lower than that of Spain (0.347), Australia (0.352), and the UK $(0.360)$, and especially of the US (0.408), Singapore (0.485), Hong Kong (0.514), and China (0.469). Cf. Ibid. for Asian countries. For the others, cf. "Inequality in Income or Expenditure / Gini Index," UNDP Human Development Report 2007/08.

29. Cf. DGBAS, http://www.stat.gov.tw/public/Data/843016151671.doc.

30. Cf. DGBAS MacroEconomics Database, op. cit, et F. Blanc, "Bilan économique des années Chen Shui-bian," op. cit. In 2007, the average monthly wage in industry and services was NT\$45,112. In 2000, it was NT\$41,938, and in 1994 NT\$33,689. There was, however, a significant drop (about 16 hours) in the number of hours worked per month between 1994 and 2007. 
2001 recession, combined with lower - or even stagnant wage growth for a portion of the population (the upper classes remaining notably unscathed) has thus given the Taiwanese a feeling of relative impoverishment, intensified by the fall in the Taiwanese dollar against many other currencies, which was caused by the central bank's decision to maintain parity with the US dollar to support exports. ${ }^{(31)}$

Ma Ying-jeou's biggest problem on the economic front, therefore, will be to improve an economy that is doing well but faces acute problems in terms of stagnation of middle and lower class incomes, redistribution of national wealth, and restructuring of the industry and services sectors. ${ }^{(32)}$ These questions were not really tackled during the electoral campaign, so much of the population tends to believe that the solution to these problems is faster GDP growth, to be achieved in particular by greater economic interaction with China. The fact is, however, that one of the main causes of growing unemployment since the mid-1990s, especially among unskilled workers, is the relocation of labour-intensive industries to China and Southeast Asia. ${ }^{(3)}$ Another factor is members of the Taiwanese business community, known as Taishang, who have migrated to the mainland and taken their consumption with them; these are mainly entrepreneurs and white collar workers, qualified and well paid, who comprise, with their families, more than a million people, or 5 percent of the Taiwanese population. Lastly, since the mid 1990s, the rise in capital income (finance and property) has outstripped that of earned income, contributing to rising social inequality while low tax revenue ( 13 percent of GDP) limits redistributing of national wealth. ${ }^{(34)}$

Since the problems are not temporary but structural, the KMT and Ma will find them no easier to solve than did the DPP. Indeed, the promised closer relations with China will intensify the migration of business, no longer affecting only low technology - that relocation was completed by the mid 1990s - but high technology as well, particularly semi-conductors, flat screens, and possibly Taiwan's heavy industry. At the same time, there is no guarantee that the agreement on direct air links with China or increased numbers of Chinese tourists (rising to 3,000-10,000 a day compared with 1,000 now) will bring a real increase in growth and revenue outside the sectors of air transport and tourism. Still more problematic will be the opening up of Taiwan to Chinese investors, particularly in commercial and residential property, when access to house ownership is already increasingly difficult for young families in Taipei, and signs of a real estate bubble have already appeared. ${ }^{(3)}$ Lastly, the tax cuts announced by the new KMT government are likely to endanger the balanced budget so hard won by the DPP since 2006 (at a time when revenue from taxation is already among the lowest in the industrialised countries), and may encourage the government to resort to debt in order to finance state expenditure. ${ }^{(36)}$

Perhaps more promising is the attempt to change Taiwan into a regional financial centre for the research, development, and logistics needed to take full advantage of China's growth. This project, which Vice-President Siew had already proposed as Prime Minister under Lee Teng-hui (1997-2000), now has better chances of success with the improvement of Taiwan's technical and professional capabilities and the expected opening of direct links with China. These same links should also allow the Taishang to send profits back home, thus restoring some of their consumption to Taiwan, along with that of foreign expatriates in China. The gigantic new infrastructure programme proposed by $\mathrm{Ma}$ should also, once its funding has been resolved, provide a spur to public investment and supply much-needed jobs, even though the toughest minimum-wage construction work (at NT\$17,000) attracts only immigrant workers from Southeast Asia, as has been the case since the 1990s. It remains to be seen how the new government will manage to further develop the services sector to provide new jobs for both unskilled labourers and professionals while boosting incomes across the board.

\section{Relations with China}

Relations with China constitute a further major challenge for Ma Ying-jeou, at the political level in particular. The KMT's proposals for closer economic ties should win support from Beijing and from the Taiwanese people as long as they benefit from them. As for the gradual establishment of air links (passenger and cargo) and the opening to Chinese tourists, the technical negotiations between Taipei and Beijing were already settled in 2007 under the DPP. Ma

31. The value of the Euro has thus increased more than 50 percent, from NT\$30 in 2001 to NT\$48 in 2008.

32. Cf. Ting-I Tsai, "What to do about the Widening Income Gap," Taiwan Business Topics, 37-2, February 2007

33. Cf. C. Meer, J. Adams, "Specter of Inequality Haunts Taiwan," op. cit.

34. Cf. Ting-I Tsai, "What to do about the Widening Income Gap," op. cit.; Chan Huo-sheng, Hsue Cheng-tai, "Exploring M-shaped Society and Policy Implications for Taiwan," NPF Research Report, National Policy Foundation, Taipei, 23 January 2008.

35. Joyce Huang, "Real Estate Experts Warn of Potential Oversupply," Taipei Times, 2 May 2008.

36. Cf. Jerry Lin, Kevin Chen, "KMT Facing Three Main Challenges, Economists Say," Taipe Times, 23 March 2008; F. Blanc, "Bilan économique des années Chen Shui-bian," op. cit. 
should therefore be able to swiftly receive the political "gift" that Beijing was denying to Chen with the start of direct weekend charter flights promised for July 2008.

The basis of Ma's China policy is the acceptance of the "one China, different interpretations" (yizhong gebiao) compromise (which already produced the 1992-3 technical agreements between Taipei and Beijing) and of the concept of "mutual non-denial" between the two capitals. ${ }^{(37)}$ Yet, its success depends almost entirely on China's understanding and goodwill. As the recent encounter between Vincent Siew and Hu Jintao at the Boao Forum suggests, Beijing does seem ready to play the game and to maintain a positive cross-Strait dynamic, while remaining vague about its agreement on the "double interpretation." (38) Ma's victory and the failure of the referendums on Taiwan joining the $\mathrm{UN}$ are in fact very good news for Beijing. But with Ma in power, the Chinese Communist government also finds itself in a more complex situation. For eight years, Beijing was easily able to treat $C h e n$ as a villain, blaming him for poor cross-Strait relations while demanding his respect for a "one China" concept that was unacceptable to the DPP administration and relying on Washington to apply its Taiwan policy. Although the Chinese Communist Party (CCP) has revised its aim of rapid reunification, aiming instead to block Taiwan's progress towards independence, it has hardly moved on the basic principle of recognising the ROC; nor has it proposed any framework for political integration more considerate of Taiwan's wishes and realities than the "one country, two systems" formula.

Furthermore, contrary to what the present discourse of the KMT and the CCP might suggest, the recent political tensions between Taiwan and China long predate Chen's accession to power; his policy towards China was essentially a continuation of Lee's. ${ }^{(39)}$ In fact, even if the leaders of the SEF and its Chinese counterpart, ARATS, managed to meet in 1998 in Shanghai, official contacts between the two capitals have almost been at a dead end ever since Lee's 1995 visit to the US, followed by the Chinese missile tests in Taiwanese territorial waters, all that at a time during which the ruling KMT adhered to the so-called "1992 consensus". ${ }^{(40)}$ Beijing will therefore now be obliged to demonstrate that its own inflexibility is not blocking political relations with Taipei; it will have to propose measures that answer Taiwanese expectations of being better represented in international bodies and of an end to the diplomatic war against their country.

In Ma Ying-jeou Beijing also comes up against a president who is very attached to the ROC, its legitimacy, and its history. Ma is one of the few politicians, even among mainlanders, to keep alive the flame of the May Fourth Movement, which he has celebrated every year in a public statement. Even more fundamentally, any peace accord between the two sides will be impossible until Beijing acknowledges the fact that all Taiwanese people, the KMT foremost among them, consider the ROC in Taiwan to be a sovereign and independent state. $\mathrm{Ma}$ is also concerned about democracy in China, repeatedly asking for an official re-evaluation of the Tiananmen events, religious freedom in China and Tibet, and an end to the repression of Falun Gong, attitudes that hardly endear him to the CCP. ${ }^{(41)}$

Observers will be watching to see what Beijing can offer Ma to maintain the interest and goodwill of the Taiwanese towards China at a time when increasing operating costs (labour and raw materials) are pushing many small and medium-sized Taiwanese businesses to reconsider their presence on the mainland. ${ }^{(42)} \mathrm{Ma}$ will need concrete results, and not just symbolic progress, to prove the validity of his China policy. For Washington, Ma's election is also an opportunity for detente that Beijing should not miss. ${ }^{\left({ }^{(3)}\right)}$ The first tests will be sorting out Taiwan's membership in the WHO and other international organisations and groupings, and at the defence level, a withdrawal or reduction in the number of missiles targeting Taiwan. On his side, Ma has nothing to gain from appearing to cosy up too quickly to Beijing and to compromise with an authoritarian and anti-democratic government. Indeed, much of his presidency's success will depend on his effective defence of the interests and sovereignty of Taiwan, in full respect for the Taiwanese identity of which he has declared himself guarantor.

37. Dimitri Bruyas, "Ma repeats 'mutual non-denial' policy," The China Post, 24 March 2008.

38. Cf. William Foreman, "Taiwan VP-Elect Meets China's Hu," Associated Press, 12 April 2008; D. Brown, "Taiwan Voters Set a New Course," op. cit.

39. Cf. Mikael Mattlin, "Same Content, Different Wrapping: Cross-Strait Policy Under DPP Rule," China Perspectives, n56, November-December 2004, pp. 26-33.

40. Cf. Richard Bush, "Lee Teng-hui and 'Separatism,'” in N. Tucker, Dangerous Straits: The U.S.-Taiwan-China Crisis, op. cit., pp. 70-92. The term "1992 Consensus" was created in 2000 by Su Chi, then Minister of Mainland Affairs. However, the existence of such a consensus was contested by the DPP administration as well as by Koo Chen-Fu, the leader of the semi-official Strait Exchange Foundation (S.E.F) in charge of the 19921993 talks with China, as Beijing never recognized the "double interpretation" of the One China principle (yizhong gebiao).

41. Cf. Willy Lam, "Ma Ying-jeou and the Future of Cross-Strait Relations," China Brief, vol. $8, n^{\circ} 7,28$ March 2008.

42. Cf. Ting-I Tsai, "China's Labor Law a Last Straw for Taiwanese," Asia Times Online, 14 December 2007.

43. Cf. Bonnie Glaser, "If Not Now, When? Will China Seize the Opportunity to Improve Cross-Strait Relations?", Pac-Net Newsletter, 29 April 2008. 


\section{National identity}

Ma's victory and his new Taiwanese identity are the best proof that Chen Shui-bian's two terms in office helped to consolidate the Taiwanese national identity and the Taiwanisation of society as a whole. ${ }^{(4)}$ Ma's victory is of symbolic importance in that he is the first mainlander (waishengren) to be democratically elected President of Taiwan by a population that is 85 percent local (benshengren). It marks the end of an epoch and of a policy based on the distinction between benshengren and waishengren that was first instituted with the arrival of Chiang Kai-shek's troops on the island in 1945, and engendered the political and economic segregation of the benshengren under dictatorship. Democratisation brought a sociopolitical re-adjustment in favour of the benshengren, a process crowned by the election of Chen to the presidency. ${ }^{(4)}$ The ever-growing support of the people for Taiwanese identity, and for Taiwanese independence, is thus in no way contradicted by the return to power of a Taiwanised KMT; ${ }^{(4)}$ rather, the election of Ma marks the emergence at the highest state level of the "new Taiwanese society" through democratisation. It marks, indeed, the success of Lee Teng-hui's policy of Taiwanising the Republic of China and the KMT and of changing mainlanders into "new Taiwanese" (xin taiwanren). ${ }^{(4)}$

Taiwan's successful national self-affirmation and establishment of identity since the 1990s has made these issues of less pressing concern, allowing space for other preoccupations, economic ones in particular. Yet, Taiwanese national identity remains at the heart of political debate. It is built on very particular historical foundations going back to at least 1895, and should prove lasting even though in a constant state of evolution. At the same time, the continuing tensions between the island's political development and its closer economic relations with China have endowed its people with a fervent attachment to the status quo of de jure and de facto sovereignty and independence for Taiwan as the Republic of China, peace on the ground with China, and protection from the US. The majority of Taiwanese people, wishing to preserve what they have and conscious of the Chinese military threat, are ready to soft-pedal their national claims, putting off any resolution of the question until a later date. ${ }^{(48)}$ However, as long as China remains undemocratic and has not reached Taiwan's level of prosperity, there is no chance that the Taiwanese would favour political unification.

Indeed, Taiwanese society continues to evolve differently from China's. Whereas during the 1980s some people expected that the effect of trade and capitalism would bring the two societies together, they have actually moved further apart as democracy has become established in Taiwan and a new generation has succeeded the old. The massacre of 28 February 1947 and the Kaohsiung Incident of 1979 no longer resonate much among many young people; this is even more true of the mainlanders' Chinese past and the Qing Empire. More than half of today's population was born after 1970 and came (or will come) to political maturity in a democratic and Taiwanised environment. Few things connect them to Chinese society, whether at the political, social, or cultural levels, or in terms of mentality. Furthermore, despite the naive aspirations of some, close economic and commercial links between two countries have never of themselves created a common national identity, as attested by the case of Canada and the US (although English-speaking Canada is united with its neighbour by language and Anglo-Saxon culture). Admittedly, the growth in the numbers of Taiwanese citizens living in China has redoubled contacts between the two peoples, but that has not necessarily brought the Taiwanese closer to the Chinese or made them stakeholders in the same community. If anything, closer contact has made Taiwanese more aware of the differences between the two societies: living habits, education and behaviour, treatment of others, openness to the outside world, appreciation for foreign cultures and countries (for the US and Japan in particular), experience and knowledge of Chinese culture (religion, art of living, and so on), and, above all, political freedom and democracy, not to mention the respect for Taiwanese culture, the respect for the rule of law and for an impartial legal environment, and Taiwan's social security and health system. Often, the Taiwanese appreciate China mainly as consumers: their approach is financial, careerist, or touristic, with the exception of a small minority attached to Greater Chinese nationalism. Many supporters of the Pan-Blues, including the mainlanders, prefer thus to live in and come home to Taiwan while supporting new economic links and the lowering of tension across the Strait.

44. Cf. Daniel Lynch, "Mr. Ma’s Taiwanese Identity," Far Eastern Economic Review, vol. 171, $n^{\circ} 2$, March 2008

45. Cf. Chang Mau-kuei, "Toward an Understanding of the Sheng-chi wen-ti in Taiwan," in Chen Chun-min et al. (ed.), Ethnicity in Taiwan. Social, Historical and Cultura Perspectives, Taipei, Institute of Ethnology, Academia Sinica, 1994, pp. 93-150.

46. Cf. Christopher Hughes, "The 2008 Legislative Yuan Election and the Complex Nativisation of the KMT," Taiwan Perspective, $n^{\circ} 118,20$ February 2008.

47. Cf. Stephane Corcuff, "Taiwan's "Mainlanders" New Taiwanese?", in Memories of the Future, Armonk (NY), M. E. Sharpe, 2002, p. 163-195.

48. Cf. Mainland Affairs Council, Combined Analysis Report on Public Opinion Surveys on Cross-Strait Relations in 2007, MAC, Executive Yuan, R.0.C, Taiwan, 1 January 2008. 
Understanding all this, Ma tuned his message to the wishes of the Taiwanese people, and they rewarded him with their votes. Now he will have to continue representing the interests of the majority of the Taiwanese who wish to maintain the status quo and not to be dragged by the KMT's radical unificationists into excessive concessions towards Beijing. Democratisation has been an essential element in forming the Taiwanese national identity and its domestic and foreign policies ever since the 1990s. It has enabled the Taiwanese to support Lee Teng-hui's policy of national self-affirmation abroad, and then to oppose Chen Shui-bian's too-rapid pursuit of independence; now it will be the means of controlling the new KMT government's policy on relations with China.

\section{Conclusion}

The 2008 elections marked the end of the Chen Shui-bian era and ushered in the new Ma era. They also marked the end or at least the decline of ethnic politics in favour of a wider and more solid policy of national identity. Taiwan, a model of democracy for the region and the world, has demonstrated once again that democratic values and human rights are entirely compatible with Chinese or Asian culture. Numerous issues now await Ma's attention, most particularly the national "reconciliation" that people are hoping for after years of ideological tension. His choice of a former TSU deputy close to Lee Teng-hui as the new Minister for Mainland Affairs is a first gesture towards the ProIndependence camp. ${ }^{(49)}$ However more will be needed to ease the Creens' anxiety about the real depth of Ma's new Taiwanese identity in regard to his known Chinese nationalism.

For the rest, the incoming governmental team is composed mainly of old KMT technocrats (with past experience of the country's administrative affairs during the 1990s) and academics. It projects itself also as a government of experts in the service of the economy and the people.

The Taiwanese people are thirsty for international status and recognition and will soon demand from the new administration practical results in this area. But if Ma manages to keep his promises and to improve the situation of the middle class while respecting Taiwanese identity, he might become a very popular president, and barring accidents, may position himself favourably for re-election in 2012. •

\section{- Translated by Philip Liddell}

\section{The New Taiwanese Government}

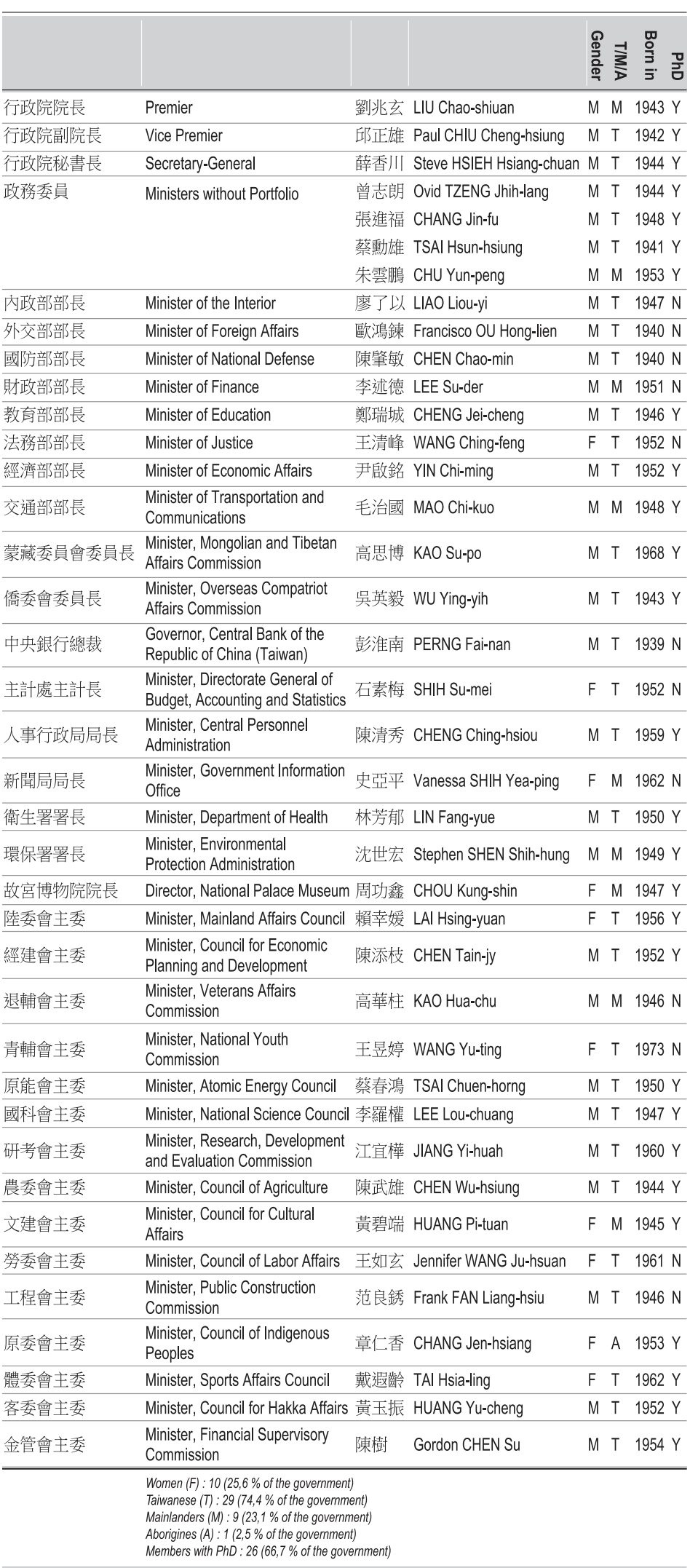

49. Cf. Flora Wang, "Liu names major Cabinet posts," Taipei Times, 29 April 2008 